Originalveröffentlichung in: Benjamin W. Roberts, Christopher P. Thornton (Hg.), Archaeometallurgy in global perspective. Methods and syntheses, New York 2014, S. 239-268

Chapter 11

\title{
Provenance Determination of Archaeological Metal Objects
}

\author{
Ernst Pernicka
}

\section{A Short History of Provenance Analysis of Archaeological Metal Objects}

The application of scientific methods to the analysis of metals goes back to the very beginnings of analytical chemistry in the modern sense, as the first quantitative analysis of any metal alloy was performed on a Roman coin and published by Martin Heinrich Klaproth in the late eighteenth century. In this study, he mainly addressed the question of material composition. However, within a few decades the idea of provenance determination was formulated, for example by Göbel (1842), who published an article entitled: "On the impact of chemistry on the tracing of prehistoric peoples, or results of the chemical investigations of ancient metal objects, especially of those from the Baltic region, to determine the peoples from whom they derive" (my own translation). He suggested from the geographical distribution of about 120 analysed objects that they represented well-defined ethnic groups as was normal during that time.

It should be remembered that the three-age system had been proposed only a few years before (by C. J. Thomsen in 1836) and that an additional motivation for the analyses was the hope that metal objects could be dated based on their compositions. However, already in the nineteenth century it was discovered that this was a moot point and the interest of researchers concentrated on the question of provenance. Soon thereafter, it was proposed that minor elements were more useful in determining the nature of the ore from which the metal came and perhaps even its geographical origin (von Fellenberg 1860-1867; von Bibra 1869). Furthermore, it was found that compositional differences between copper metals were to be expected when native copper, oxide or sulphide ores were used for smelting (Wibel 1863), an idea

\footnotetext{
E. Pernicka ( $\triangle)$

Institut für Ur- und Frühgeschichte und Archäologie des Mittelalters,

Abteilung für Jüngere Urgeschichte und Frühgeschichte, Schloß Hohentübingen,

Eberhard-Karls-Universität Tübingen, 72070 Tübingen, Germany

e-mail: ernst.pernicka@cez-archaeometrie.de
}

University of Tübingen and Curt-Engelhorn-Zentrum Archäometrie, Mannheim, Germany

B. W. Roberts, C. P. Thornton (eds.), Archaeometallurgy in Global Perspective, 
repeated almost exactly a hundred years later by Friedman et al. (1966). However, the analytical methods available then did not allow further progress because of the large sample requirements and a small sample throughput.

Although most scholars agreed that trace elements were most indicative of the ore sources, the limited analytical means of that time did not allow them to make use of this knowledge. Accordingly, there was little further progress until the late 1920 s, when instrumental analytical techniques became available. They were almost immediately applied to the concept of provenance studies of ancient metals. As an example, the Sumerian Metals Committee, inspired by the exceptional finds at the Royal Cemetery at Ur in Mesopotamia (Woolley 1931), was appointed by the Royal Anthropological Institute to investigate the origins of Mesopotamian metals. The committee reported on the origin of Sumerian copper, assuming that its nickel content could be indicative of an ore source in Oman (Desch 1928-1938). Oman was suggested as a possible region of origin because it was known that the basic and ultrabasic rocks there (so-called ophiolites) are enriched in nickel. The problem is that there are also ophiolites on Cyprus and in eastern Turkey, so that without field work the problem cannot be resolved. From these interim reports, it is obvious that the original objective was not really achieved, but they resulted in the creation of a further unit, the Ancient Metal Objects Committee, in 1939.

\section{Halle}

With the advent of atomic emission spectrometry around 1930 (Gerlach and Schweitzer 1930), it became possible to determine many trace elements in reasonably small samples of a few milligrams with sufficient sensitivity (in the range of $0.001-0.01 \%$ ) and in a short time. This opened the door to systematic studies of ancient metals, beginning in 1931 by W. Witter, a prehistoric archaeologist based in Halle with a background in mining engineering. Witter was later joined by $\mathrm{H}$. Otto and together they began to systematically analyse all available metal objects in Germany from the Neolithic to the Early Bronze Age (Otto and Witter 1952). They were motivated by two aims: to determine whether there was Bronze Age copper mining in Germany and to develop a methodology for relating archaeological objects back to specific ore deposits. They refined their method to allow for the analysis of ten elements ( $\mathrm{Fe}, \mathrm{Co}, \mathrm{Ni}, \mathrm{Cu}, \mathrm{As}, \mathrm{Sn}, \mathrm{Ag}, \mathrm{Sb}, \mathrm{Pb}, \mathrm{Bi}$ and $\mathrm{S}$ ) in some 1,300 objects within a few years - much more than had been accomplished over the preceding 100 years.

Otto and Witter then classified the objects according to their compositions into six groups that were based on the general knowledge of copper ore mineralogy. These groups were (in chronological order): (1) very pure copper; (2) unalloyed copper with minor impurities; (3) arsenical copper; (4) fahlore metal with high concentrations of arsenic, antimony and silver; (5) copper with nickel and arsenic as major impurities and (6) copper-tin alloys. This is the beginning of the concept of "Leitlegierungen" (major alloy types), which is generally still valid with the exception of the last group. As was later shown by the Stuttgart group (see below), very pure copper is typical of 
the fifth and early fourth millennia BC in southeast and central Europe, and arsenical copper dominates in the fourth and early third millennium. At the beginning of the Early Bronze Age, fahlore metal is most abundant in central Europe, which is later replaced by copper with arsenic and nickel as major impurities. As will be shown below, some of these copper types can indeed be related to certain mineralised regions, although it is usually difficult to pinpoint the exact mine.

A major deficiency of this study was the lack of an equal number of analyses of copper ores from deposits that were considered to be likely sources for the analysed artefacts. Although in their publication, Otto and Witter (1952) explicitly emphasised the necessity to analyse also ores and slag from ancient smelting sites, only a few examples from the geological literature were used for comparison. Furthermore, the ore deposits were implicitly considered to be homogenous and to be differentiated in their compositions. For the comparison of artefact and ore analyses, they did not consider the changes in chemical composition during smelting and used all measured elements including tin, which is obviously an alloying element as tin and copper ores rarely occur together. Using this approach, they concluded that $97 \%$ of all prehistoric metal objects found in Germany were produced from copper ores in Saxony. Although this conclusion cannot be supported today, and was most likely influenced by nationalistic preoccupations, it is nevertheless a pioneering study, both from the methodological view and from the archaeological scope. It was the first large-scale attempt to determine the provenance of prehistoric metals with an appropriate analytical method, based on a large number of analyses and a classification method that was governed by substantial knowledge in economic geology. The importance of field work was also clearly expressed as well as the idea that chemical analyses could provide evidence for ancient exploitation of mines that do not have any visible remains of ancient mining due to modern activities.

\section{Vienna}

Parallel with the investigations in Halle, another group in Vienna under the direction of Richard Pittioni and Ernst Preuschen worked along similar lines. They specifically set out to determine "from which production area a specific object would derive" (Preuschen and Pittioni 1937). Their emphasis was on field work and mining archaeology, both having been educated as mining engineers. Accordingly, they not only had a more realistic view of the problems of characterising ore deposits geochemically, but they actually performed a large number of analyses on ore samples, mainly from prehistoric mining districts in Austria. More than 2,000 ore analyses formed the database on which they attempted to establish a clear relationship between "ore deposits and finished objects". Unlike the Halle group, the Vienna group was aware of the fact that trace element concentrations in ore deposits can be quite variable and that the concentrations are further altered during the production of copper metal. Using this knowledge they decided that the sensitivity of the analytical method should be more important than its reproducibility, because only the presence 
or absence of a certain element should be used to determine the trace element pattern as a whole. While this is generally true, it was an unfortunate decision, because they did not attempt to actually quantify the spectra but estimated the concentrations by visual inspection of the spectral lines on a film detector. This resulted in semiquantitative analyses without numerical values for the concentrations so that they are hardly usable today. They also used the objects and ores directly as electrodes to avoid any alteration of the chemical composition during sample preparation. This, however, meant that only the surfaces of the objects were analysed, which are often not representative of the whole composition.

The Vienna group classified more than 6,000 analyses of artefacts, from the central European Bronze Age, into five groups that they assigned to different ore deposits in the eastern Alps and in Slovakia. There was much dispute between the two groups about the correct methodological approach, which continued when the methodology that was developed in Halle was continued in an even larger project in Stuttgart. However, the Vienna group is credited with the insight that provenance analysis of metal artefacts has to be accompanied by field work in ancient mining districts. Indeed, the results of their mining archaeological research have long remained without parallel.

\section{Stuttgart}

Considering the problems of relating metal artefacts to specific ore deposits, a new group in Stuttgart and Freiburg directed by Siegfried Junghans and Edward Sangmeister decided not to search for the origin of the raw metals, but simply use the chemical analyses of metal objects as an independent criterion for classification in addition to conventional typologies. They assumed that prehistoric metal workers would receive their raw metal primarily from the same source(s), similar to potters, and that they also applied similar processes to produce copper. If this assumption holds, then one would try to identify workshops rather than to identify the mines where the ore would have come from. By preparing distribution maps of copper types that were identified based on their chemical composition, it was hoped that one would obtain insight into the production and distribution of metals in Europe. For this purpose, more than 22,000 objects from all over Europe (Junghans et al. $1960,1968,1974)$ were sampled and analysed with practically the same method as in Halle.

In order to identify workshops, the analytical results were grouped according to their chemical similarity: first into 12 (Junghans et al. 1960) and later into 29 groups (Fig. 11.1). The grouping method used statistical methods of variance analysis (Junghans et al. 1954) based on histograms of the elemental concentrations. It was found that five elements contributed most of the variance of the data, namely $\mathrm{Ag}, \mathrm{Ni}$, $\mathrm{As}, \mathrm{Sb}$ and Bi. In the histograms of these elements, several peaks were observed. The minima between such peaks were defined as limits between different groups. This is 


\section{Stuttgart Stammbaum}

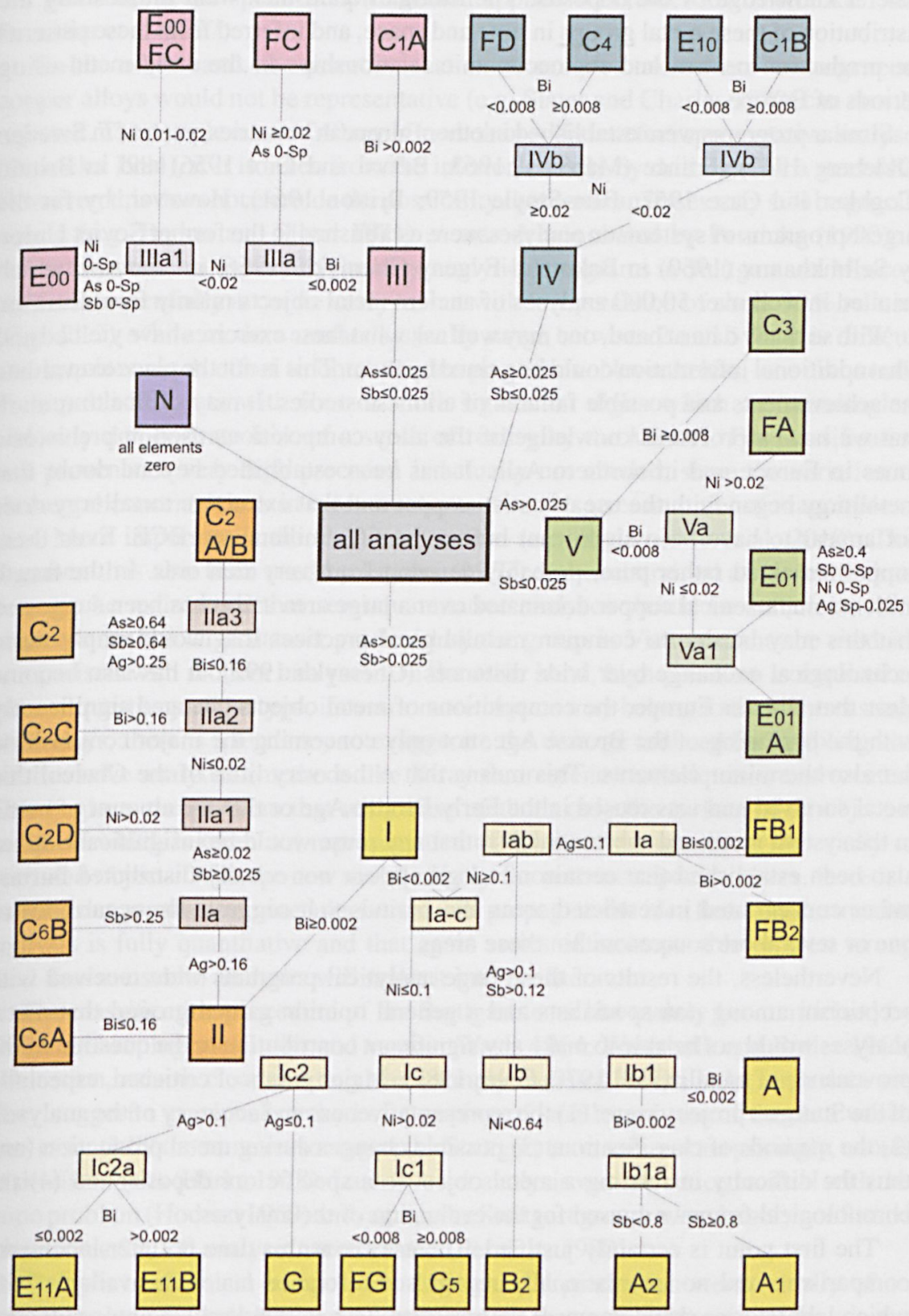

Fig. 11.1 The classification scheme developed and used by the Stuttgart team to find chemically similar prehistoric copper objects 
certainly a reasonable procedure, but for many archaeologists it lacked the clearness of the groups defined in Halle and Vienna by their "Leitlegierungen" based on the general knowledge of ore deposits. The Stuttgart team then went on to study the distribution of these metal groups in time and space, and inferred from these patterns the production centres and socioeconomic relationships in the early metal-using periods of Europe.

Similar programs were established in other European countries, such as in Sweden (Oldeberg 1942), France (Maréchal 1963; Briard and Giot 1956) and in Britain (Coghlan and Case 1957; Blin-Stoyle 1959; Britton 1961). However, by far the largest programs of systematic analyses were established in the former Soviet Union by Selimkhanov (1960) in Baku and Evgeny Chernykh (1966) in Moscow, which resulted in well over 50,000 analyses of ancient metal objects mainly from Eurasia.

With so many data at hand, one may well ask what these exercises have yielded and what additional information could be gained by them. This is not the place to evaluate the achievements and possible failures of all these studies. It may suffice to remark that we have a profound knowledge of the alloy compositions used in prehistoric times in Europe and in northern Asia. It has been established beyond doubt that metallurgy began with the use of native copper and that extractive metallurgy does not appear to have been significant before the fifth millennium BCE. Even then, copper remained rather pure, probably deriving from very rich ores. In the fourth millennium, arsenical copper dominated over a large area and it has been suggested that this may be due to common metallurgical practices that would imply rapid technological exchange over wide distances (Chernykh 1992). It has also become clear that all over Europe, the compositions of metal objects changed significantly with the beginning of the Bronze Age, not only concerning the major composition but also the minor elements. This means that either very little of the Chalcolithic metal survived and was reused in the Early Bronze Age or that the amount of metal in the system increased substantially so that any reuse would be insignificant. It has also been established that certain metal groups are not equally distributed but are rather concentrated in restricted areas and periods that suggests the occurrence of one or several ore sources within those areas.

Nevertheless, the results of these large analytical programs were received with scepticism among non-specialists and a general opinion gained ground that metal analyses would not be able to make any significant contribution to the question of the provenance of metals (Hall 1970; Coles 1982). Major points of criticism, especially of the Stuttgart project, were: (1) the representativeness and accuracy of the analyses; (2) the methods of classification; (3) possible changes during metal production (and thus the difficulty in relating a metal object to a specific ore deposit) and (4) the chronological framework used for the evaluation of the analyses.

The first point is certainly justified. There were at this time no inter-laboratory comparisons and no internationally recognised reference materials available with which laboratories could compare their results. This is standard laboratory practice today, but was not applied in the early days of spectral analysis. Indeed, two programs (Chase 1974; Northover 1996) to compare the analyses of different laboratories indicated that there were many problems and that some seriously deviating results 
were produced and published. At least for the two largest series of metal analyses (in Stuttgart and Moscow), the accuracy of the data could be confirmed even though the precision of the spectroscopic method applied was rather low (Pernicka 1984; Pernicka et al. 1997).

On the other hand, the assertion that small samples taken from heterogeneous copper alloys would not be representative (e.g. Slater and Charles 1970) can now be rejected. The sample mass of $40 \mathrm{mg}$ is more than sufficient for representative analyses (Pernicka 1984), if it is taken from the interior, usually by drilling with a steel drill. However, this does not exclude the possibility that some analyses may still be grossly wrong (e.g. Barker and Slater 1971) as was demonstrated by Pernicka (1990). It rather turns out that especially the large analytical programs in Stuttgart and Moscow produced essentially accurate analyses but with low precision of about $30 \%$ relative (Fig. 11.2), while modern methods usually range between 2 and $5 \%$. It is difficult and requires much effort to obtain better precisions. Nevertheless, one frequently finds published data with four or more significant digits which are meaningless and only demonstrate lack of a sense of reality by the authors. For classification and provenance very high precision is actually not needed, since the variation of elemental concentrations in most ore deposits ranges over an order of magnitude or two. More important is the elemental pattern (e.g. Radivojević et al. 2010). This argument has also been used by Pittioni (1957) and overstrained at the same time, because he maintained that semi-quantitative analyses should be sufficient. As a consequence the large dataset produced by the group in Vienna cannot be used for comparison with modern analyses. On the other hand, high precision is required to answer questions of the type, if two or more objects may belong to the same casting. Nowadays, there is a tendency to exaggerate the damage induced by sampling and non-invasive analytical methods like X-ray fluorescence techniques are advocated. This neglects the problem that with these methods only the surface of an object is analysed which is often not representative of the metal composition, especially of corroded objects. With the new mobile X-ray fluorescence spectrometers, there is a definite danger that untrained personnel will propagate the idea that non-destructive analysis is fully quantitative and that again series of incomparable or even wrong (and thus unusable) analyses will make it into the literature.

The classification procedure of the Stuttgart team has mainly been criticised by Dutch archaeologists (Butler and van der Waals 1964; Waterbolk and Butler 1965) but it soon became clear that they were simply overstrained with the large data set. They suggest a graphical method of grouping of smaller subsets of the data which uses essentially the same reasoning as the Stuttgart team and, not surprisingly, comes to similar results (Härke 1978). Later, cluster analysis was introduced to deal with the same problem (Hodson 1969) and, again, the Stuttgart groups were largely confirmed when some 25,000 analyses were treated (Pernicka 1990).

Changes in chemical composition during metal production were actually of no concern as long as workshops were sought and not the geological origin of the copper. Some confusion and reluctance to accept the conclusions of the Stuttgart team may well be due to the chronological system used at the time for the archaeological interpretation, which adhered to "conventional" dates, especially for the southeast 

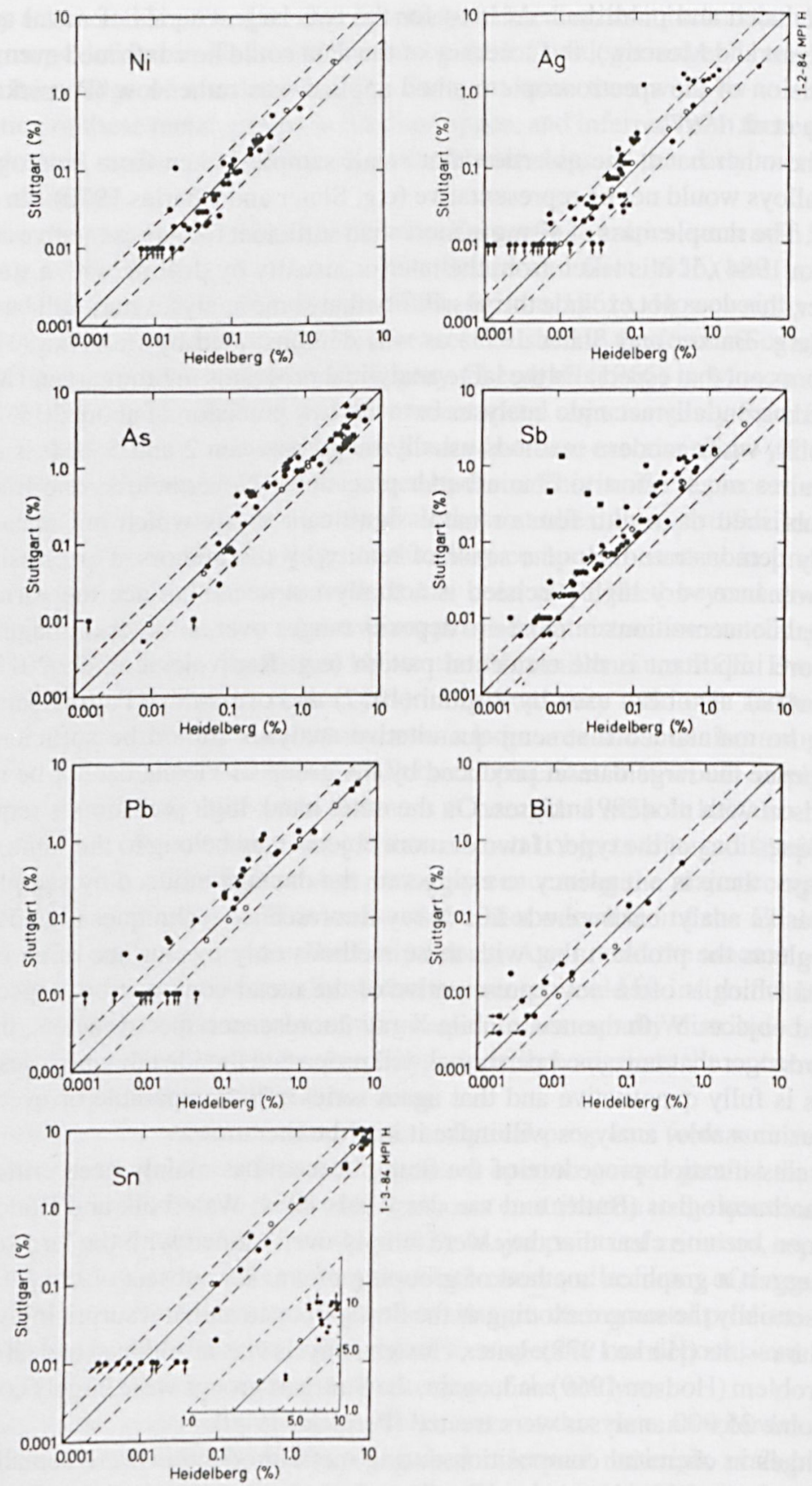

Fig. 11.2 Comparison of analyses obtained with atomic emission spectrometry at the Württembergisches Landesmuseum in Stuttgart ("Studien zu den Anfängen der Metallurgie" analyses) with results obtained with neutron activation analysis $(\mathrm{As}, \mathrm{Sb}, \mathrm{Ni}, \mathrm{Ag}$ and $\mathrm{Sn}$ ) and atomic absorption spectrometry $(\mathrm{Pb}$ and $\mathrm{Bi})$ at the Max-Planck-Institute for Nuclear Physics in Heidelberg (from Pernicka 1990). The four outliers in the Sb diagram (indicated as squares) are due to an interference from Fe. (Pemicka 1984) 
European Copper Age. However, it has to be remembered that the Radiocarbon Revolution (Renfrew 1973) had not yet occurred in European prehistory. A re-evaluation of the Stuttgart data based on the material classification by Pernicka (1990) has been attempted by Krause (2003). In summary, the very large analytical programs seem to have been ahead of their time despite the lack of a consistent chronological framework for all of Europe, a computer technology that could deal with such large datasets, or the analytical stringency that nowadays is a standard practice in professional laboratories. The high hopes that were originally connected with the analysis of metal objects to determine their provenance were seemingly disappointed.

\section{The Revival of Metal Provenance Through Isotope Analyses}

Some fifty years ago, new methods seemed to open a way out of this somewhat depressing situation. The earliest method was the introduction of lead isotope analysis, first applied to lead (Brill and Wampler 1965; Grögler et al. 1966) and silver (Gale et al. 1980) and later extended to copper and copper-based alloys (Gale and Stos-Gale 1981; Pernicka et al. 1984). The second method was the application of new analytical techniques that were more sensitive and more precise than the previously prevailing optical emission spectrometry. Most elements consist of different isotopes, i.e. atoms with very similar chemical characteristics but varying in weight. Compounds of elements of low atomic number can thus differ significantly in their molecular weight.

For example, $\mathrm{H}_{2} \mathrm{O}$ exists in the form of nine different isotopic varieties ranging from 16 to 22 amu (atomic mass units). The differences in the molecular weights affect the way these molecules respond to certain kinds of physical processes that are mass dependent. This leads to slightly varying isotopic compositions in different reservoirs. For example, seawater and rainwater differ in their isotopic composition, as does rainwater collected at different geographical latitudes. The study of these subtle effects (referred to as isotope fractionation) has become very important not only for the Earth sciences, but also for provenance studies of materials that contain elements of low atomic number (such as marble) or for the study of prehistoric diet. The application of this method requires that the raw material of the artefact has not undergone any change of chemical or physical state, because such processes could induce additional isotopic fractionations that could delete the original differences of the geological sources. Thus, elements of low atomic numbers are generally of little value for the study of metal artefacts.

Elements of high atomic number, on the other hand, generally show no measurable isotope fractionation in the natural environment. However, some elements such as lead consist partly of isotopes that are products of radioactive decay. For example, uranium and thorium decay with half-lives of several billion years into the lead isotopes ${ }^{206} \mathrm{~Pb},{ }^{207} \mathrm{~Pb}$ and ${ }^{208} \mathrm{~Pb}$. Lead consists of these three isotopes and a fourth, ${ }^{204} \mathrm{~Pb}$, that is not produced by radioactive decay. It is evident that the lead isotope composition of the Earth will change through geologic time scales. It is also evident 
Fig. 11.3 Basic principles of provenance determination of ancient metal objects with lead isotope ratios

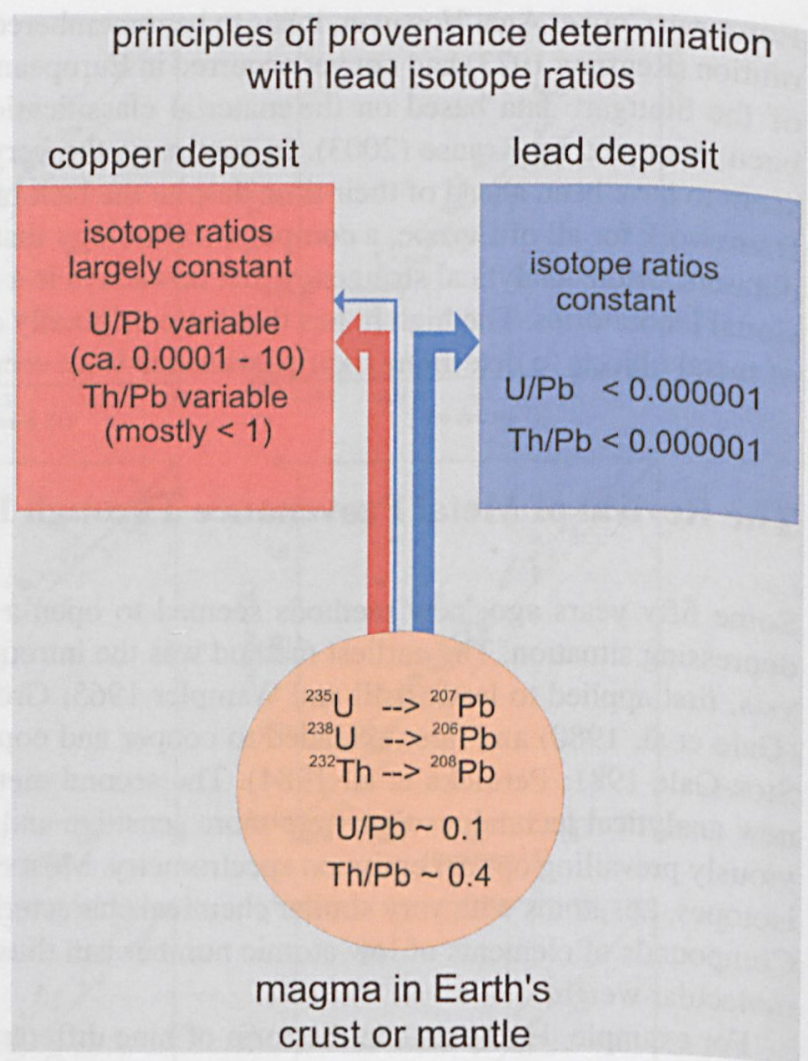

that lead deposits in the Earth's crust can vary in their isotope composition, depending on their geological age and the $\mathrm{U} / \mathrm{Pb}$ and $\mathrm{Th} / \mathrm{Pb}$ ratios of the geological reservoir that supplied the lead. By the formation of a lead deposit, these elemental ratios are changed by many orders of magnitude so that any further contribution by the decay of uranium and thorium becomes insignificant and the lead isotope composition becomes fixed. It is also then extremely unlikely that the lead isotope ratios will be altered by any of the physical and chemical processes that occur during the metallurgical process from ore to finished artefact, save for the mixing of lead of different origins. By and large the same arguments apply to lead in copper deposits; thus, lead isotope analysis can also be applied to copper-based metal objects (Fig. 11.3).

The advantage of looking at the isotopic composition of an element, rather than at abundances (or the abundance pattern) of minor and trace elements, is that the isotopic composition of a heavy element like lead does not change on the way from ore to artefact. Regardless of the processes involved in the treatment of ores or metalwhether it is roasting or smelting, cupellation or melting, alloying, dissolution or corrosion-the isotopic composition remains constant. Most of these processes are diffusion controlled and from physical laws one can deduce that measurable (i.e. in the permille range) effects can only be expected when the mass difference between two species or isotopes is larger than $10 \%$. The largest mass difference of the stable 
lead isotopes is $4 \mathrm{amu}$, just about $2 \%$. Isotope fractionation of lead can be induced in the laboratory, if lead is volatilised (e.g. by converting it into hydride) and almost completely removed from the sample. This has been observed (Pernicka, unpublished) but there is no similar process in copper metallurgy. It would certainly have to be considered with volatile elements such as mercury and zinc, if one would like to use their isotope ratios for provenance studies. This has two important consequences. First, neither the exact pathway from ore to artefact, nor the metallurgical techniques employed, need to be known. While both processes affect the behaviour of trace elements and govern how the elemental abundance pattern in ores relates to that in the metal, they have no bearing on the isotopic composition.

Second, the isotopic composition is not dependent on how lead is distributed between different phases. That is, different segregated phases in artefacts may have grossly different lead contents, but the lead will have the same isotopic composition. Similarly, there are no noticeable differences in the isotope abundances between the lead in slags and that in the complementary metal. Thus, sample heterogeneity (which is notorious for making many chemical analyses difficult to interpret) is of no relevance for the isotopic composition. Of course, a prerequisite for even attempting to utilise isotope abundance measurements for provenance studies is that the isotopic composition of lead from different parts of the world must vary. This is indeed the case, and the variations found in nature are many times larger than the analytical precision with which the composition can be determined.

Once there are a sufficient number of isotope measurements of an ore deposit available, it can be considered to be isotopically characterised. The question of how many measurements are required cannot be answered in a general way. Some deposits show a small variation in their lead isotope ratios and those are the ones that can best be used for provenance discussions. It is often found that lead ore deposits show this behaviour. In such cases, five to ten analyses may be sufficient for their charactersiation. On the other hand, there are lead deposits with large variations (e.g. the so-called Mississippi Valley Type deposits or MVT deposits) and then even 50 analyses may not be sufficient. It is now increasingly recognised that many copper deposits with low lead concentrations exhibit large variations in their lead isotope ratios. In such deposits, the assumption described above that the lead isotope ratios do not change after their formation does not apply, because the $\mathrm{U} / \mathrm{Pb}$ and $\mathrm{Th} / \mathrm{Pb}$ ratios may not be reduced to insignificant values. Accordingly, radiogenic lead will alter the lead isotope ratios even after the formation of the deposit. Since uranium and thorium are bound to be heterogeneously distributed in minerals on a small $(\mathrm{mm}$ to $\mathrm{cm}) \mathrm{scale}$, a large range of lead isotope ratios can develop since the formation of the deposit. This was first recognised in the Chalcolithic copper mine at Rudna Glava in Serbia (Pernicka et al. 1993) and later in many other copper deposits like Feinan in Jordan, the Erzgebirge in Saxony and in the greywacke zone of the eastern Alps. But even under these circumstances one can come to reasonable conclusions, if larger groups of ore and artefact samples are compared (e.g. Höppner et al. (2005).

Nevertheless, also lead isotope ratios of single artefacts can be compared with those of an ore deposit. If they are different, then it can be concluded that the 
artefacts do not derive from that specific ore source. Conversely, it is not possible to regard the provenance of an artefact as proven, even if it shares the same isotopic signature as an ore deposit. The reason for this is that although the variation of lead isotope ratios in ore deposits is much smaller than that of trace element concentrations, there exists the possibility that another deposit has the same lead isotope ratios. This is indeed increasingly being recognised as more deposits become characterised.

In the early days of lead isotope analysis in archaeology, neglecting this simple logic sometimes led to affirmative statements concerning the provenance of copper artefacts that did not stand up to later results. Thus, the general pattern of overoptimistic expectations followed by disappointment (as with trace element studies) seems to have been repeated with isotope analysis. It has also been stated that only lead isotope ratios are useful for provenance studies, while chemical analyses cannot match copper-alloy artefacts to their parent copper ores. Although this is often correct, there are cases where the trace element pattern may be more indicative of an ore source than lead isotope ratios. At Feinan (Jordan), for example, the ore deposit is chemically homogeneous but shows wide variations in its lead isotope ratios (Hauptmann et al. 1992).

With four stable lead isotopes, one has a maximum of three independent variables (i.e. lead isotope ratios). These could be plotted in a three-dimensional space but usually one uses two diagrams, in which the same lead isotope ratio is plotted on the abscissa and the two others on the ordinate (Fig. 11.4). As is obvious from the diagrams, lead isotope ratios are strongly correlated, which results in their alignment along a straight line, which further reduces their discrimination power, because they occupy only a minor part of the theoretically possible space, resulting in a tendency for different ore deposits to overlap. In such a situation, it is common sense that a combination of both sets of data-lead isotope ratios and trace element concentrations-will provide better discrimination between different sources.

\section{The Information from Trace Elements}

In provenance studies, only those elements that follow copper during smelting are useful, which means that the element/copper ratio largely remains the same between the ore and the final product. Five major complications and misconceptions have to be considered at this point. First, ores are generally inhomogeneous on all scales. The opinion has often prevailed that this precludes any correlation between artefacts and ores. However, this need not be so as the prehistoric mining region of the Mitterberg in Salzburg (Austria) shows. Here, trace element concentrations in chalcopyrite-rich ores vary over two orders of magnitude, yet this variation is not a random one. It is known, for example, that nickel in this region occurs mainly in the form of $\mathrm{Ni}-\mathrm{As}$ minerals such as gersdorffite (NiAsS), so that copper produced from Mitterberg ores is characterised by a combination of about equal concentrations of nickel and arsenic as major impurities at variable concentrations combined with relatively low contents 


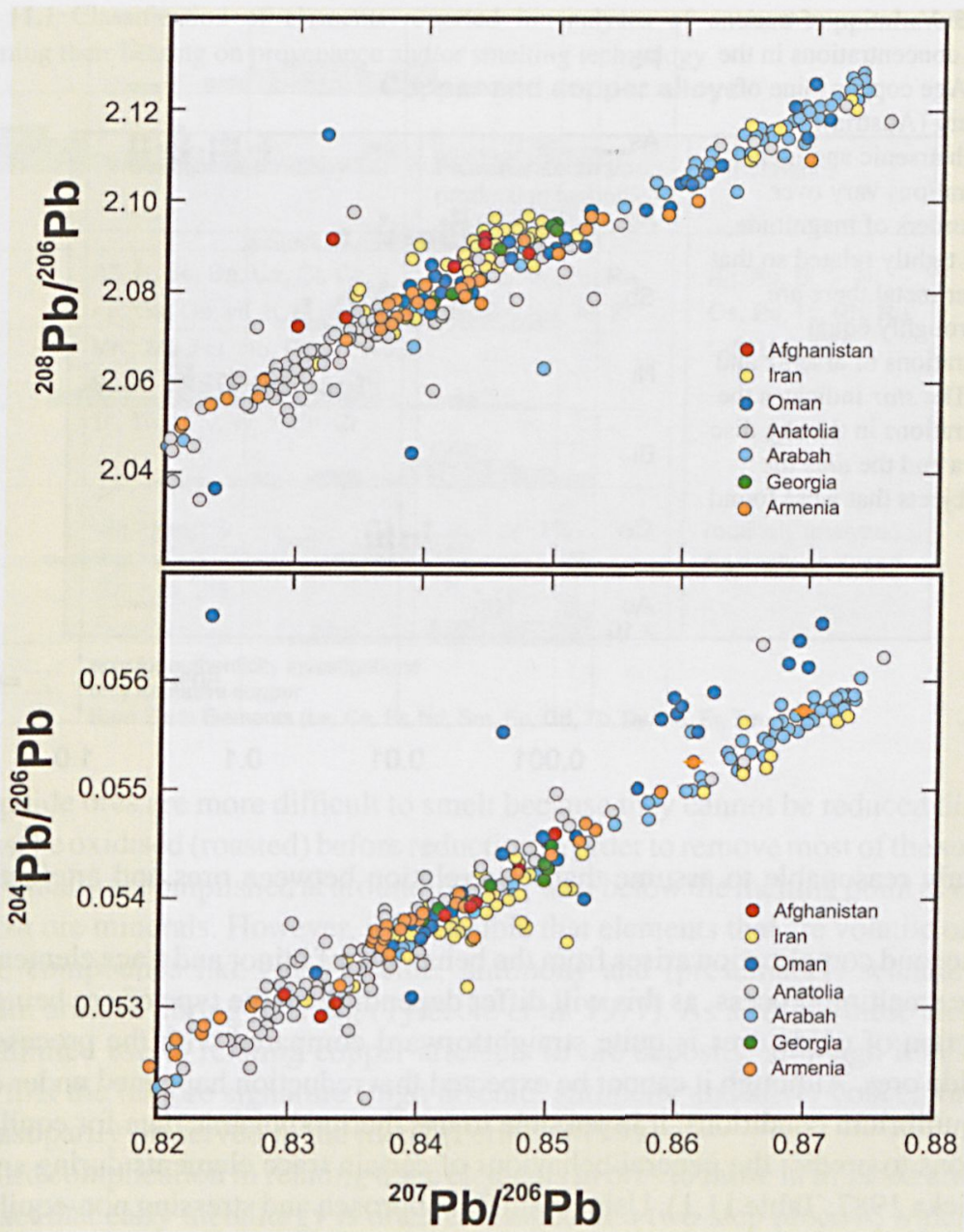

Fig. 11.4 Lead isotope ratios in copper ores, copper slag and native copper from some 170 occurrences in Southwest Asia (Afghanistan, Iran, southern Caucasus, Anatolia, Arabah valley and Oman). The analytical uncertainties are comparable with the size of the symbols. Although there is some separation between the (presently analysed) copper ores from various regions visible, it is obvious that it would be impossible to determine the provenance of a metal object from Mesopotamia, for example, with lead isotope ratios alone. (Data are from: Begemann and Schmitt-Strecker 2009; Seeliger et al. 1985; Wagner et al. 1986, 1989, 2007; Hauptmann et al. 1992, 2003; Begemann et al. 2003; Begemann and Schmitt-Strecker 2009, Yener et al. (1991); Hirao et al. (1995); Sayre et al. (2001); Nezafati et al. (2009); Pernicka et al. (2011) and Meliksetian and Pernicka (2010))

of antimony, silver and bismuth (Fig. 11.5). In a study of some 1,200 Bronze Age copper artefacts from the adjacent area, it was found that about $80 \%$ of the copper alloys conformed to this general pattern. Knowing that the peak production period at the Mitterberg was during the Late Bronze Age Urnfield culture (about 1,300-800 BCE), 
Fig. 11.5 Variation of trace element concentrations in the Bronze Age copper mine of Mitterberg (Austria). Although arsenic and nickel concentrations vary over several orders of magnitude, they are tightly related so that in copper metal there are always roughly equal concentrations of arsenic and nickel. The star indicates the concentrations in the sky disc of Nebra and the dots the metal objects that were found with it

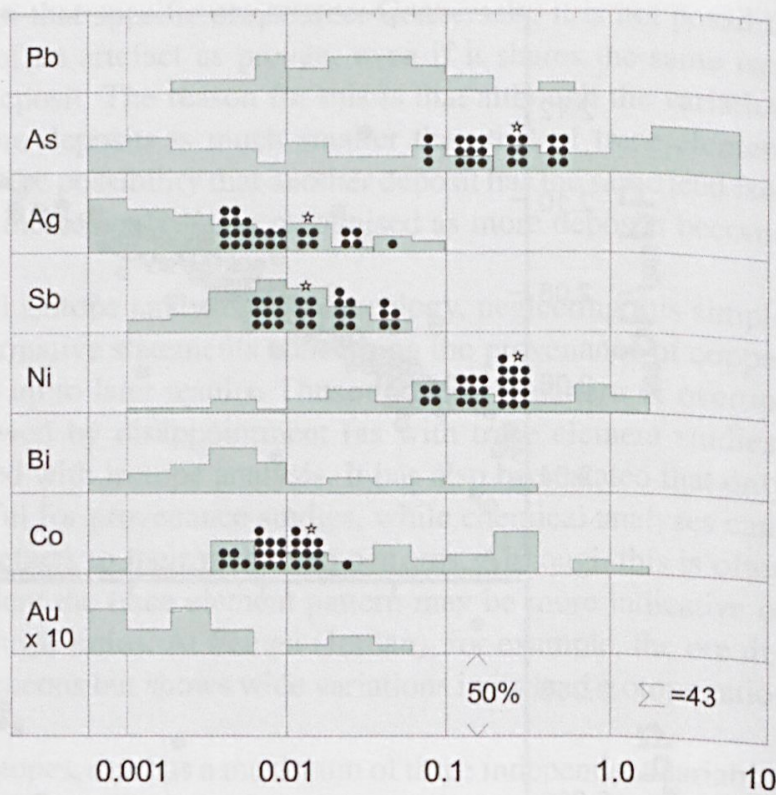

it is only reasonable to assume that a correlation between ores and artefacts does exist.

A second complication arises from the behaviour of minor and trace elements during the smelting process, as this will differ depending on the type of ore being used. Reduction of oxide ores is quite straightforward compared with the processing of sulphide ores. Although it cannot be expected that reduction happened under chemical equilibrium conditions, it is possible to use thermodynamic data for equilibrium reactions to predict the general behaviour of certain trace elements during smelting (Pernicka 1987; Table 11.1). Using a similar approach and stressing non-equilibrium conditions, it was suggested that the concentration of some elements (notably nickel and arsenic) strongly depends on the smelting temperature and that copper (with or without nickel) could be produced from the same ore (Pollard et al. 1991). This is, however, a very theoretical possibility and requires the assumption that high and low impurity coppers were being produced intermittently due to different smelting temperatures. It is hard to imagine that ancient smelters did not know what they were doing and so sometimes smelted with low efficiency and without slag formation below the melting point of copper and at other times at very high temperatures above $1,200^{\circ} \mathrm{C}$. It is far more likely that people who were able to cast copper and thus achieve temperatures above $1,100^{\circ} \mathrm{C}$ would strive to smelt at the maximum temperature obtainable with charcoal (between 1,200 and $1,300{ }^{\circ} \mathrm{C}$ ). Under these circumstances, both slag and metal are liquid and the smelting process is easier to control and much more efficient. Consequently, it is most likely that the reduction smelting of ores containing nickel and arsenic would produce copper rich in both elements. 
Table 11.1 Classification of elements reported in analyses of ancient copper-based objects concerning their bearing on provenance and/or smelting technology

Copper and copper alloys

\begin{tabular}{|c|c|c|}
\hline Production technology & $\begin{array}{l}\text { Provenance and/or } \\
\text { production technology }\end{array}$ & Provenance \\
\hline $\begin{array}{l}\mathrm{Al}^{a}, \mathrm{~B}, \mathrm{Be}, \mathrm{Ba}, \mathrm{Ca}, \mathrm{Cr}, \mathrm{Cs}, \\
\mathrm{Fe}, \mathrm{Ga}, \mathrm{Ge}, \mathrm{Hf}, \mathrm{K}, \mathrm{Li}, \mathrm{Mg}^{\mathrm{a}}, \\
\mathrm{Mn}^{\mathrm{a}}, \mathrm{Mo}, \mathrm{Na}, \mathrm{Nb}, \mathrm{P}^{a}, \mathrm{~Pb}, \mathrm{Rb}, \\
\mathrm{S}, \mathrm{Sc}, \mathrm{REE}^{\mathrm{c}}, \mathrm{Si}^{\mathrm{a}}, \mathrm{Sn}, \mathrm{Sr}, \mathrm{Ta}, \\
\mathrm{Ti}^{\mathrm{a}}, \mathrm{Th}, \mathrm{U}, \mathrm{V}, \mathrm{W}, \mathrm{Y}, \mathrm{Zn}, \mathrm{Zr}\end{array}$ & $\begin{array}{l}\text { As, Co, In, } \mathrm{Pb}, \mathrm{Re} \\
\mathrm{Sb}, \mathrm{Sn}, \mathrm{Se}, \mathrm{Te}, \mathrm{Zn}\end{array}$ & $\begin{array}{l}\mathrm{Ag}, \mathrm{Au}, \mathrm{Bi}, \mathrm{Ir}, \mathrm{Ni} \\
\mathrm{Os}, \mathrm{Pd}, \mathrm{Pt}, \mathrm{Rh}, \mathrm{Ru} \\
\mathrm{Cd}^{\mathrm{b}}, \mathrm{Hg}^{\mathrm{b}}, \mathrm{Tl}^{\mathrm{b}}\end{array}$ \\
\hline $\begin{array}{l}\mathrm{Sn}>\text { ca. } 1 \% \\
\mathrm{~Pb}>\text { ca. } 5 \% \\
\mathrm{Zn}>\text { ca. } 2 \%\end{array}$ & $\begin{array}{l}\mathrm{Sn}<\text { ca. } 1 \% \\
\mathrm{~Pb}<\text { ca. } 5 \% \\
\mathrm{Zn}<\text { ca. } 2 \%\end{array}$ & $\begin{array}{l}\text { routinely analyzed } \\
\text { routinely analyzed }\end{array}$ \\
\hline
\end{tabular}

Sulphide ores are more difficult to smelt because they cannot be reduced directly, but must be oxidised (roasted) before reduction in order to remove most of the sulphur. This is usually accomplished at around $700^{\circ} \mathrm{C}$, well below the melting point of copper and most ore minerals. However, it is possible that elements that are volatile or form volatile compounds like zinc, arsenic, antimony and (presumably) selenium and tellurium are lost during roasting (Tylecote et al. 1977). As a result, these elements are of limited use to relating copper artefacts to ore deposits, although it has been shown that the fahlore signature (high arsenic, antimony and silver concentrations) is at least partly preserved in the metal (Pernicka 1999).

A third complication in relating trace elements in ores to those in finished artefacts is the fact that early metallurgy is often envisaged as a two-step process, which may leave little or no slag-the so-called slagless process. According to this model, there is first the reduction of copper ore to copper metal in a solid-state reaction, which requires reducing conditions and temperatures from $700^{\circ} \mathrm{C}$ upwards (Budd 1991), and second there is the actual melting of copper metal, which requires temperatures in excess of $1,080^{\circ} \mathrm{C}$. In this two-step model, the reducing stage is characterised by the necessarily incomplete burning of charcoal, which results in limited heat generation and may lead to the reduction of some copper oxide to copper metal. This metal would form in a finely dispersed form within any gangue components (such as iron oxides or silicates) that come together with the copper mineral. Any copper formed in this hypothetical process would then have to be melted in order to collect it and cast it into an artefact shape. To do this, one would have to raise the temperature above $1,084^{\circ} \mathrm{C}$, the melting point of copper.

This hypothetical scenario is rather unrealistic. There are several physicalchemical and practical arguments against it: 
Fig. 11.6 Curve 1 in the figure shows the equilibrium relationship for the reaction $\mathrm{CO}_{2}+\mathrm{C}=2 \mathrm{CO}$, which is called Boudouard's equilibrium. In the neighbourhood of $1,200 \mathrm{~K}$, carbon dioxide that has been formed by burning of charcoal is changed into carbon monoxide by this reaction, making it possible to maintain the reducing capability of the gas. It is evident that below $1,000 \mathrm{~K}$ the reducing capability of the gas decreases rapidly

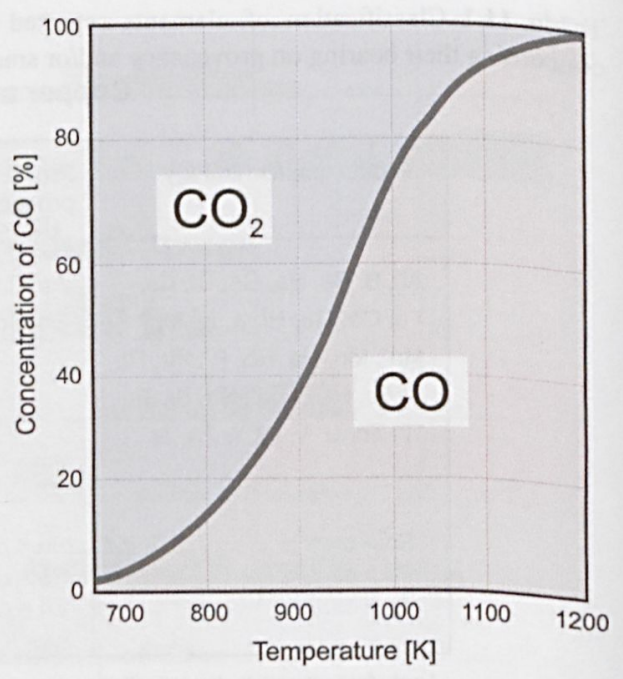

1. Reduction of copper to metal is much more efficient in the liquid phase due to much higher diffusion rates.

2. The reducing agent is gaseous carbon monoxide (CO) in all cases, which is produced when there is an excess of charcoal in contact with the burning charcoal. This so-called Boudouard equilibrium of the reaction $\mathrm{CO}_{2}+\mathrm{C}=2 \mathrm{CO}$ favours the $\mathrm{CO}$ side only above ca. $800^{\circ} \mathrm{C}$ (Fig. 11.6). Below this temperature, the reduction efficiency (i.e. the amount of $\mathrm{CO}$ present) would be very low, so that the postulated solid-state reduction at such a moderate temperature would be very slow.

3. Finally, it would be very difficult for the ancient smelter to keep the temperature relatively low throughout the reaction vessel, due to inevitable temperature gradients from the tip of the blow pipe to areas further away. In effect, it would be difficult to control the temperature in the region between 800 and $900{ }^{\circ} \mathrm{C}$ if one were determined to reduce copper at such a low temperature. Therefore, it is highly unlikely that the early smelters consciously aimed at such a two-step process. It is much more likely that the two discrete aspects of copper smeltingchemical reduction and physical melting-may well have been combined in one process. The suggestion of a purely solid-state and "slagless" copper production remains hypothetical at best, even for the earliest periods of metallurgy.

The fourth complication arises from the treatment of smelted copper to produce the finished object. Nowadays, black (the first product of a smelting furnace) or "dirty" copper is generally refined to remove sulphur, iron and other impurities and this may also have been true in prehistoric times. This is an easy process because all that is required is to re-melt the copper under mildly oxidising conditions. Iron and other easily oxidised impurities are then removed as dross. It has been suggested that the refining of copper erases most of the chemical characteristics that survived from the ore (Merkel 1983, 1990). However, using Merkel's experimental data it can be shown that this is not the case for elements like silver, nickel and antimony (Fig. 11.7). 
Fig. 11.7 Summary of refining experiments performed by Merkel (1983, 1990). It is evident that the concentrations of most elements relative to copper do not significantly change on simple re-melting, except for $\mathrm{Fe}, \mathrm{S}$ and Mo, all of which are irrelevant for provenance studies. It is unlikely that molten copper was regularly exposed to a blast of air for extended time as indicated in the third column (re-melted and oxidised copper). But even then, only $\mathrm{Co}, \mathrm{Ni}$ and $\mathrm{Pb}$ are reduced by a factor of 2 , which is of little significance when ores are compared with artefacts. (After Pernicka 1987)

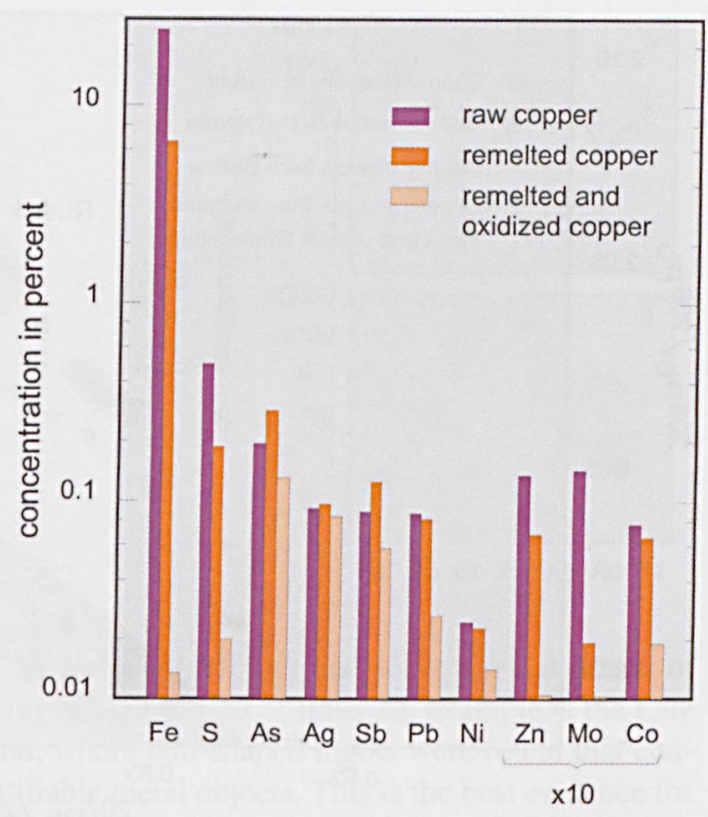

A final consideration is that some elements were deliberately alloyed to copper. In antiquity these were mainly arsenic, tin, lead and zinc. Copper-arsenic alloys have long been seen as accidental products of arsenic-rich copper ores and this may still be true in many cases. However, only recently it has been shown that speiss (an iron arsenide of variable composition) produced from arsenopyrite without copper may have been added to molten copper to enhance its arsenic content (Thornton et al. 2009; Rehren et al.). The effect on the trace element pattern of the copper is as yet unclear, but arsenopyrites are known to often contain gold so that the content of at least this element and possibly others as well may be altered compared with the copper ore. On the other hand, alloying with tin most likely produces little change in the trace element pattern of the copper as most cassiterites $\left(\mathrm{SnO}_{2}\right)$ are rather pure and the alloy usually contains an order of magnitude less tin than copper. Addition of lead to copper or bronze can alter the silver and antimony concentrations but not those of nickel, cobalt and gold. The effect of the addition of zinc to copper is difficult to assess, because this could only be achieved by the so-called cementation process, in which zinc metal in the vapour phase is taken up by the copper. Most likely there will be little change of the trace element pattern but some experimental research on this question would be helpful.

Since arsenopyrites and cassiterites usually contain very little lead, the effect on the lead isotope ratios of the copper should be minimal and is usually neglected. The opposite is true for the addition of lead. If it is assumed that lead was added intentionally to an alloy then the lead isotope ratios can only be used to discuss the provenance of the lead and not the copper. How can the intentional addition of lead be detected? This is not straightforward, because many copper deposits also contain lead minerals and substantial amounts of lead could accidentally be included in the 


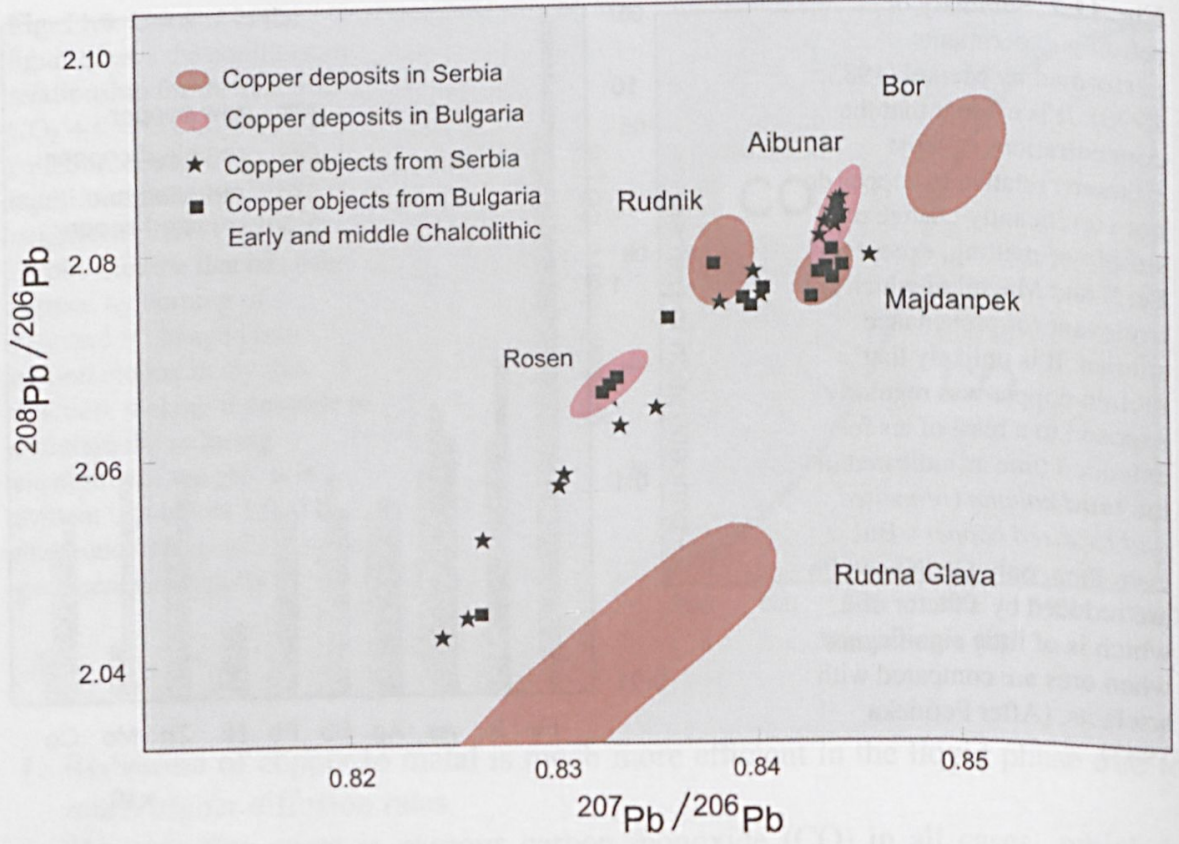

Fig. 11.8 Lead isotope ratios in various copper deposits in southeast Europe and in Chalcolithic copper artefacts (Pernicka et al. 1993, 1997). This shows that the major copper sources in this period, namely Ai Bunar in Bulgaria and Majdanpek in Serbia, partly overlap in their lead isotope ratios

copper. It is usually assumed that lead concentrations above $5 \%$ most likely indicate intentional addition of lead and that below $1 \%$ it is almost certain that there was no intentional addition. The region in between is a matter of discussion, depending on the date of the objects, their context and so on.

Table 1 contains a summary of the information provided by various elements that, in principle, can be found in ancient copper. There are few elements that are solely indicators of provenance. However, in very early times, when deliberate alloying did not occur, a whole suite of elements are available that can be useful in helping to determine provenance. The provenance of Chalcolithic copper in the Balkans (Pernicka et al. 1993, 1997) may serve as an example. Two of the earliest copper mines presently known, Ai Bunar in Bulgaria and Majdanpek in Serbia (only indirectly shown to have been exploited in the fifth millennium BC), have partly overlapping lead isotope signatures (Fig. 11.8) but can be differentiated by their trace element pattern (Fig. 11.9).

Finally, one of the most frequent questions relating to provenance analysis of copper alloys deals with mixing either of ores or of metal, for example recycling of scrap metal. In the earlier literature it was sometimes maintained that this can be recognised and taken into account. Today we realise that mixing of metals from different sources destroys the information on provenance of each component completely. This would be the case if many different metal pieces from random sources 
Fig. 11.9 Trace element patterns of Chalcolithic copper objects that are attributed to a Ai Bunar (Bulgaria) and b Majdanpek (Serbia) based on lead isotope ratios and their chemical compositions. The richest ore sample from Ai Bunar (solid line) is entirely consistent with this pattern

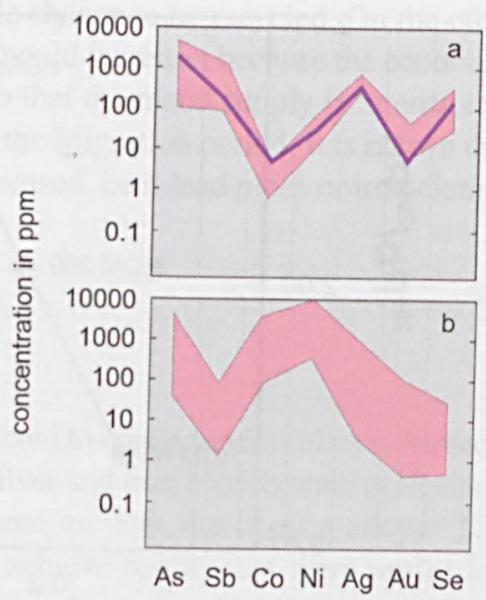

were mixed. But how realistic is this model? Mixing and recycling did occur, of course, but often within a certain region and period of time. An example is the Late Bronze Age of western Switzerland, where bun-shaped ingots were found that contained semi-molten pieces of identifiable metal objects. This is the best evidence for recycling that one can ask for. Nevertheless, Rychner and Kläntschi (1995) were able to identify local groups of metal objects of identical composition so that at least their classification was possible. It seems that in this case, recycling occurred within a pool of metal that was available and came from one source only. Thus, it is apparent that mixing did not obscure all information on provenance.

Another case that is often encountered when metal analyses are discussed is the question of whether a certain metal composition can be explained as a mixture of two other compositions. This problem was tackled in a systematic way by Pernicka (1987), who investigated whether any of the 46 metal objects could be derived from a mixture of any other two objects from the same suite. For this purpose, he compared lead isotope ratios and trace element concentrations (Fig. 11.10). The result was negative, at least for this limited problem. If one has to assume that more than two metal compositions were mixed, then there is no chance to calculate a mixing model, because the boundary conditions are not known. However, if mixing and reuse of metal would regularly occur, then there would be a tendency towards a homogenisation of the composition and no metal groups would be identifiable at all. As the opposite is observed (i.e. metal artefacts do group meaningfully), one can conclude that mixing and recycling was not important, at least in the early metal ages. Generally, one can state that the concentration of any element in an object on the extreme end on either side of the frequency distribution should indicate the absence of mixing. If, for example, an object shows a very low concentration of gold (e.g. less than a factor of ten below the average value of about $10 \mathrm{mg} / \mathrm{kg}$ ), then its overall composition cannot be derived from mixing, unless one assumes the utterly improbable case that only copper scrap with unusually low gold concentrations was mixed. The same applies for very high concentrations of elements such as antimony or nickel, which are often found in the Early Bronze Age of central Europe and the Middle East/Caucasus. 


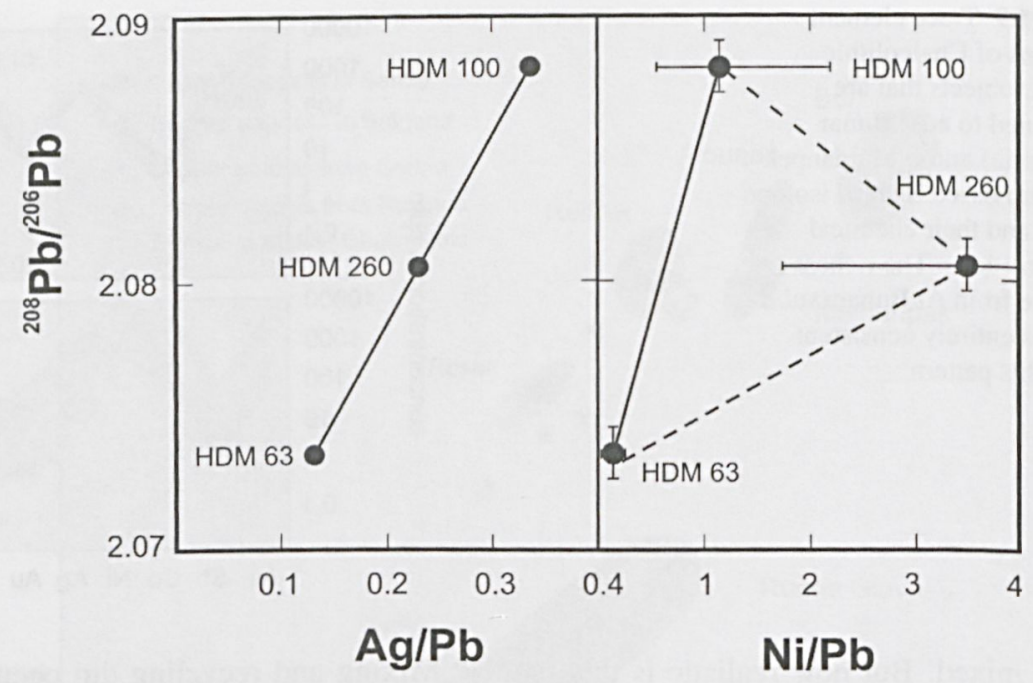

Fig. 11.10 Mixed diagram of one lead isotope radio and two element/lead ratios to demonstrate the method to identify mixing between two metal compositions. Plotted are the compositions of two metal objects from Troy (HDM 100 and HDM 260) and one from the Troad (HDM 63) published by Pernicka et al. (1984). From the left diagram one could conclude that sample HDM 260 could be a mixture of HDM 100 and HDM 63, because it plots exactly on the mixing line between the two concerning the lead isotope ratio and the $\mathrm{Ag} / \mathrm{Pb}$ ratio. Note that simply plotting the silver concentration would not be correct, because the position of a sample on the mixing line of lead isotope ratios depends on the lead concentrations of the mixed components. However, in the case of mixing, similar lines must be obtained with all other element/ $\mathrm{Pb}$ ratios. In this example, this is obviously not the case as shown in the right part of the diagram. Even if one allows for the possibility of a concentration change of a factor of 2 on melting (indicated by the horizontal error bar, the vertical error bar is the uncertainty of the lead isotope measurement), then sample 260 cannot be explained as a mixture of samples HDM 100 and HDM 63.

The question of recycling is so obvious because we are living in an era where the resources of some metals are becoming scarce and recycling is an economic necessity. The modern recycling rate of copper is the highest among all engineering metals and well above $50 \%$. But was this always so? The answer is most probably no, but this depends again on the period considered and the region. In Europe, one can identify certain compositional groups of copper-based objects that are restricted in time and space. This would not be possible if recycling of metal from widely distributed sources were the rule. Note that recycling of copper from one source within a limited area would not have the same effect. On the other hand, in metalpoor regions like Mesopotamia, recycling was probably more important than in others. There is textual evidence of recycling and, indeed, low tin concentrations up to $2 \%$ begin to become more abundant towards the end of the third millennium BCE (Hauptmann and Pernicka 2004). Such low tin concentrations do not alter the properties of the alloy significantly and are usually interpreted as indication for recycling scrap metal. Generally, one can assume that in expanding economies, the recycling rate should be small, because fresh metal must come into the system. If metal objects were removed from the system in the same period, either by loss or by 
intentional deposition, then this metal had little chance to be recycled. On the other hand, in declining cultures, the recycling rate should increase, because the economic structures become obsolete or are destroyed so that the metal supply is interrupted. A good example is the late Roman Empire and the Migration period. It is known that all kinds of old metal was actively sought and reused, be it lead pipes or iron clamps from buildings.

\section{Other Metals}

Attempts to elucidate provenance was not restricted to copper and its alloys. Already in the nineteenth century, series of analyses of silver and iron objects were performed (von Bibra 1873). The problems were the same as with the copper alloys. The analytical methods were not yet developed to achieve results that were useful for archaeology. After 1950, ancient silver was frequently analysed but concentrated on a narrow artefact group, namely coins (e.g. Gordus 1967), and it was often not the provenance of the silver that was sought but rather the alloy composition, especially the silver content. More focussed on provenance was the study of trace elements in Roman lead (Wyttenbach and Schubiger 1973) that could and should have been complemented by lead isotope analysis, which had already been introduced to the investigation of archaeological material (Brill and Wampler 1965; Grögler et al. 1966).

The pioneering work on the provenance of ancient silver was performed at the Max-Planck-Institut für Kernphysik in Heidelberg, where extensive field surveys for lead and silver deposits in the Aegean were combined with trace element and lead isotope analysis of ancient silver coins (Gale et al. 1980). Until the Middle Ages, silver was almost exclusively produced from argentiferous lead ores by a twostage process, whereby lead ores were first smelted to produce lead metal that was then selectively oxidised in the molten condition to produce lead oxide until a small amount of silver remained (a process known as "cupellation"). The remaining lead in the silver is an ideal tracer for the provenance of the metal as has been shown by later work on Early Bronze Age finds (for a summary of the research in the Aegean, see Gale and Stos-Gale 1981; Pernicka 1990). In later periods, one has to take into account that cupellation was also used to purify the noble metals silver and gold. The lead used for this process may derive from a different source than the silver and be irrelevant for the provenance thus be irrelevant for the provenance of the silver. There is circumstantial textual evidence for this practice in the second millennium BCE. In the Roman period it is likely that debased silver coinage was purified this way and, beginning in the fifteenth century $\mathrm{CE}$, lead metal was used to extract silver from argentiferous copper ores. In the Middle Ages, silver coinage was frequently recalled and re-minted so that provenance studies with this group of artefacts are fraught with problems.

For provenance investigations of lead, its isotope ratios are clearly the most valuable parameter. Trace element concentrations can be useful, if it can be assumed that the metal is the product of primary smelting. This is usually indicated by its silver content. Below a certain silver concentration it was not practical or economical to 
extract the silver, and lead was then used for other purposes. In the Bronze Age, this limit of silver extractability seems to have fallen from somewhere between 500 and $800 \mathrm{mg} / \mathrm{kg}$ to $200-300 \mathrm{mg} / \mathrm{kg}$ until it reached around $100 \mathrm{mg} / \mathrm{kg}$ in the Roman period, where it remained so until the eighteenth century CE. However, lead that has been desilvered through cupellation carries no memory of the trace element pattern of the original ore.

In principle, the problems associated with provenance studies of base metals and silver should not apply to gold, because this element mainly occurs in the metallic form in nature. Therefore, one would think that the analytical problem should be similar to rocks (e.g. obsidian, marble etc.) and that there would be no compositional change between the natural occurrence and the finished product. Unfortunately, this is not the case. There are several reasons why provenance determination of gold is even trickier than with base metals:

1. Gold is relatively pure in nature, although usually admixed with substantial silver contents (leading to natural electrum). This requires a very sensitive analytical method. Combined with the exceptional value that is always ascribed to ancient gold objects, the analytical task is formidable, because sampling is either not allowed or restricted to extremely small sample masses. The best method today is certainly mass spectrometry with inductivelycoupled plasma excitation combined with laser ablation sampling (LA-ICP-MS).

2. Silver as the major "impurity" in native gold exhibits a wide range of variation within gold occurrences so that it is of little use to discriminate between gold sources.

3. The majority of gold occurs in the form of small flakes either as alluvial gold or in rocks, which are usually powdered and the gold is extracted from the powder by some sort of panning. For manufacture, the gold was most certainly melted and this process induces significant changes in the trace element pattern of the gold (Hauptmann et al. 1995).

4. Many of the gold sources exploited in the past are geochemically insufficiently explored so that it is difficult to define characteristic elements for their discrimination. However, a pilot study has indicated that this may be possible (Schmiderer 2008). It has been found that many prehistoric gold objects contain more copper than is on average found in native gold. This means that copper may have been added to gold either intentionally or as a kind of contamination. This will certainly alter the trace element pattern of the alloy.

5. Native gold, especially alluvial gold, tends to have very low lead concentrations so that lead isotope analysis is either not possible (see 1) or difficult to interpret, because the source of the lead may not be always clear. In a study of Celtic gold coins, the question of provenance was not addressed because of evidence for recycling and alloying with copper (Bendall et al. 2009).

6. The hopes connected with the observation of inclusions of platinum group minerals (PGM) in ancient gold (Young 1972) concerning provenance analysis quickly evaporated when it was discovered that even within a single object the compositional (Meeks and Tite 1980) as well as the osmium isotopic (Junk and Pernicka 2003) variations were as large as found in nature. Therefore, discrimination of sources was not possible. 
In this situation, the only realistic chance for gold provenance is the trace element pattern, concentrating on trace elements like Pd and Pt that are characteristic of the gold, do not change on melting and are not introduced by alloying with copper (Guerra 2004, Ehser et al. 2011). The most comprehensive analytical study of prehistoric gold objects was performed at the Württembergisches Landesmuseum by Hartmann (1970, 1982). He used optical emission spectroscopy and published some 5,000 analyses. This study has also been received with scepticism but it showed that, similar to copper and copper alloys, certain compositional groups could be identified that showed a restricted distribution in time and space.

For a long time, provenance discussions of ancient iron were largely based on conjecture rather than objective facts. In most cases it was simply assumed that the geographically nearest iron deposit was the source sought. This was hardly disputed as there are many iron ore occurrences known compared with copper and other base metals. However, recent studies have shown that even with iron, matters are not so simple. Iron was traded in the form of bipyramidal ingots that were often welded from two heterogeneously carburised halves. In a pilot study, a series of middle and late Iron Age iron finds from the Celtic oppidum of Manching in southern Bavaria were analysed in order to determine their possible provenance by combining trace element patterns of slag inclusions. Lead isotopic analysis, well established in non-ferrous archaeometallurgy but hardly employed for iron, was introduced as a new approach (Schwab et al. 2006). The methods applied provided valuable information but each is limited in some aspects. Small-scale variations within the ores are thus reflected in the iron artefacts and even large variations cannot be separated by the methods employed. Nevertheless, it was possible to distinguish various iron ore occurrences near the settlement, and bog ores have been generally identified as most likely sources for iron smelting in the nearby of Manching. Actually, only one local bog ore deposit matches the characteristics of the iron artefacts examined in all aspects (Schwab et al. 2006). Degryse et al. (2007) proposed to adapt the combination of lead isotope with strontium isotope ratios for the provenance study of iron objects as it has already been introduced for ancient glass.

In a different and complementary approach, slag inclusions in ancient iron artefacts were analysed also with the view to obtain information on their provenance (Hedges and Salter 1979). Similar to copper, it is important to understand the chemical heritage (major and trace elements) from the ore into the iron artefacts. Much work has been invested in this direction by a French group (Coustures et al. 2003; Desaulty et al. 2009). It was demonstrated that the study of major elements in the slag inclusions allows the identification of ore groups characterised by high levels of certain elements such as P or Mn. In a first step, a group of artefacts with potentially common provenance was found and, more important, some provenance hypotheses could be rejected. By including rare earth elements in the study, it was found that their respective ratios remain constant from the original ore to the slag inclusions. Thus, if the chemical signature of a given area is known, it is possible to verify its compatibility with an artefact by performing trace element analyses of slag inclusions. This was verified by the French team for the Pays de Bray region using archaeological ore and experimental smelting. With many elements at hand, one can add multivariate methods of data analysis (as with pottery) to compare ores with slag inclusions in iron artefacts. 


\section{Conclusion}

To summarise, in this contribution the view is held that the scientific analysis of archaeological metal objects is not only a valuable contribution to archaeological research, but is necessary to correctly describe the archaeological material at the basic level. In many cases, metal finds that originally were described by the excavator as "bronze" turned out to be unalloyed copper or another copper alloy or even a different metal (e.g. silver). Analyses can also be used to classify metal objects according to their composition. This classification can be compared with the typological groups, and in the case of congruency, one may be able to identify the products of a particular workshop.

The most demanding and most difficult question relates to the provenance of the metal, especially in regions where no metallic ore deposits are known. It has been suggested that it may only be possible to identify the type of ore that has been used for primary smelting (Friedman et al. 1966; Budd et al. 1992). While it is possible to identify native copper rather securely by its trace element pattern (Pernicka 1990), despite assertions to the contrary (Maddin et al. 1980), it is more difficult to distinguish between oxidic and sulphidic ores post-smelting. The sulphur content is not a reliable indicator, as sulphur is concentrated in the metal phase and most oxidic ores contain small amounts of the primary sulphidic ore. The most reliable indicator seems to be the iron content (Craddock and Meeks 1987).

However, the key question remains to determine the geological source (or at least the original workshop) of a metal object. One may well ask why bother? Should we give up reaching for the stars and "rethink the quest for provenance" (Budd et al. 1996)? The answer is simple: we study provenance of metals because metal ores are unevenly distributed over large areas, so that some kind of long-distance transport naturally has to be assumed. Furthermore, metals are a new commodity that-much more than agricultural wealth - can be accumulated and hoarded. Accordingly, it has an influence on social dynamics that cannot be overestimated. Since metals are rare, their intrinsic value is high, so that small pieces of metal are equivalent in value of larger volumes or masses of other commodities, which made them ideal as exchange tokens. At least from the third millennium onwards, most values of all kind of merchandise were calculated in equivalent weights of metal, usually silver.

\section{What is the Future of Provenance Studies?}

These are just a few examples to show that provenance studies are important, especially for the reappraisal of hypotheses concerning contacts and relations of different regions and cultures on the basis of excavated materials and their distribution. It has taken a long time for the different strands of knowledge to be brought together that really promote our understanding of the unrecorded history of metallurgical production and exchange. The basis is, of course, a broad knowledge of the archaeological period under investigation to tackle the archaeologically relevant problems, select the appropriate material for this task and finally translate the analytical results into the 
cultural historical perspective. This applies to work in museum as well as in the field. Archaeologists are usually not trained to excavate and interpret metallurgical installations and know even less about ancient mining. Only when archaeological field surveys are combined with expert knowledge in mineralogy and economic geology can the metallurgical potential of a given region be correctly assessed. It requires a deep understanding of metallurgical practices and physical chemistry to understand the processes of metal production and the consequences for the chemical and isotopic composition of the metallic products. Last but not least, it requires a fair deal of experience in analytical chemistry to produce reliable data that do not lead us astray, as it has sometimes happened in the past.

Where do we go from here? Although a fairly good coverage of the geochemical characteristics of base metal deposits in the Mediterranean and in central and western Europe are now available, we will never reach a position as in provenance studies of obsidian where it is usually possible to pinpoint a certain geological obsidian source for every single artefact (at least in the eastern Mediterranean). Ore deposits are simply too heterogeneous, so that overlap between different sources is unavoidable. Actually, we are in the uncomfortable position that the more data we produce, the less (apparent) clarity we have. The way to escape this vice is the combination of parameters such as trace element patterns and lead isotope ratios. This may still not be successful in all cases, but important questions have been resolved in this way (such as the provenance of the Late Bronze Age oxhide ingots and Chalcolithic copper production and distribution in southeastern Europe). Furthermore, field studies will have to continue, because the most convincing relation between an ore deposit and archaeological metal artefacts is a match of the trace element patterns, lead isotope ratios and metal mining and production in the period in question, as was also demonstrated in southeastern Europe (Pernicka et al. 1997).

New parameters will be added in future and have already been tested, such as isotope ratios of copper (Klein et al. 2010), zinc (Budd et al. 1999), osmium (Junk and Pernicka 2003, Brauns et al. 2013) and recently also tin (Haustein et al. 2010). Of these, osmium may be most useful for the provenance of iron and still possibly of gold. Tin isotope ratios have already yielded a very surprising result in that it was found that the tin of the famous sky disc of Nebra most likely derives from Cornwall and not from the relatively nearby Erzgebirge, corroborating Pare's (2000) scenario of Early Bronze Age tin trade in central Europe. Provenance studies of all kinds of metal will certainly form an important component of archaeometallurgy also in the foreseeable future.

\section{References}

Barker, G., \& Slater, E. (1971). The first metallurgy in Italy in the light of the metal analyses from the Pigorini Museum. Bullettino di Paletnologia Italiana, 80, 183-212

Begemann, F., \& Schmitt-Strecker, S. (2009). Über das frühe Kupfer Mesopotamiens. Iranica Antiqua, 54, 1-45

Begemann, F., Schmitt-Strecker, S., \& Pernicka, E. (2003). On the composition and provenance of metal finds from Beşiktepe (Troia). In Wagner G. A. Pernicka E, \& Uerpmann H.-P. (eds.) Troia and the Troad-Scientific approaches (pp. 173-201). Springer, Heidelberg 
Bendall, C., Wigg-Wolf, D., Lahaye, Y., von Kaenel, H.-M., \& Brey, G. P. (2009) Detecting changes of Celtic gold sources through the application of trace element and $\mathrm{Pb}$ isotope laser ablation analysis of Celtic gold coins. Archaeometry, 51,598-625

Blin-Stoyle, A. (1959) Chemical composition of the bronzes. Archaeometry, 2,1-17

Brauns, M., Schwab, R., Gassmann, G., Wieland, G., \& Pernicka, E. (2013). Provenance of Iron Age iron in southern Germany: A new approach. Journal of Archaeological Science, 40, 841-849.

Briard, J., \& Giot, P. R. (1956). Analyses des objets métalliques du chalcolithique et de l'age de bronze ancien et du bronze moyen de Bretagne. L'Anthropolgie, 60, 495-500.

Brill, R. H., \& Wampler, J. M. (1965). Isotope ratios in archaeological objects of lead. Application of science in the examination of works of art (pp. 155-166). Boston: Museum of Fine Arts.

Britton, D. (1961). A study of the composition of Wessex culture bronzes. Based on spectroscopic analyses by E. E. Richards. Archaeometry, 4, 39-52.

Budd, P. D. (1991). Eneolithic arsenical copper-Heat-treatment and the metallographic interpretation of manufacturing processes. In E. Pernicka, \& G. A. Wagner (Eds.), Archaeometry '90: International symposium in archaeometry (pp. 35-44). Basel: Birkhäuser Verlag.

Budd, P. D., Gale, D., Pollard, A. M., Thomas, R. G., \& Williams, P. A. (1992). The early development of metallurgy in the British Isles. Antiquity, 66, 677-686

Budd, P. D., Haggerty, A., Pollard, A. M., Scaife, B., \& Thomas, R. G. (1996). Rethinking the quest for provenance. Antiquity, 70, 168-174

Budd, P. D., Lythgoe, P., McGill, R. A. R., Pollard, A. M., \& Scaife, B. (1999). Zinc fractionation in liquid brass $(\mathrm{Cu} / \mathrm{Zn})$ alloy: Potential environmental and archaeological applications. In A. M. Pollard (Ed.), Geoarchaeology: Exploration, environments, resources (pp. 147-153). London: Special Publication 165, Geological Society.

Butler, J. J., \& van der Waals, J. D. (1964). Metal analysis, Studien zu den Anfängen der Metallurgie (SAM) I, and the European prehistory. A review article. Helinium, 4,1-39.

Chernykh, E. N. (1966). Istorija drevnejšej metallurgii Vostočnoj Evropy. Moskau-Leningrad: MIA 132.

Chase, W. T. (1974). Comparative analysis of archaeological bronzes. In C. W. Beck (Ed.), Archaeological chemistry (Advances in Chemistry Series No. 138), 148-185.

Chernykh, E. N. (1992). Ancient metallurgy in the USSR. Cambridge: Cambridge University Press

Coghlan, H. H., \& Case, H. (1957). Early metallurgy of copper in Ireland and Britain. Proceedings of the Prehistoric Society, 23, 91-123.

Coles, J. M. (1982). The Bronze Age in northwestern Europe: Problems and advances. In: F. Wendorf and A.E. Close (eds.): Advances in World Archaeology 1, New York, 265-321.

Coustures, M.-P., Béziat, D., \& Tollon, F. (2003). The use of trace element analysis of entrapped slag inclusions to establish ore-bar iron links: examples from two gallo-roman iron-making sites in France (Les Martys, Montagne Noire, and Les Ferrys, Loiret). Archaeometry, 45, 599-613.

Craddock, P. T., \& Meeks, N. D. (1987). Iron in ancient copper. Archaeometry, 29, 187-204.

Degryse, P., Schneider, J., Kellens, N., Waelkens, M., \& Muchez, P. H. (2007). Tracing the resources of iron working at ancient Sagalassos (South-west Turkey): A combined lead and strontium isotope study on iron artefacts and ores. Archaeometry, 49(1), 75-86.

Desaulty, A.-M., Dillmann, P., L'Héritier, M., Mariet, C., Gratuze, B., Joron J-L, \& Fluzin P (2009) Does it come from the Pays de Bray? Examination of an origin hypothesis for the ferrous reinforcements used in French medieval churches using major and trace element analyses. Journal of Archaelogical Science, 36, 2445-2462

Desch, C. H. (1928-1938). Sumerian copper-reports of committee appointed to report on the probable source of the supply of copper used by the Sumerians, British Association for the Advancement of Science Reports: 1928, pp. 437-441; 1929, pp. 264-265; 1930, pp. $267-$ 268; 1931, pp. 269-272; 1933, pp. 302-305; 1935, pp. 340-344; 1936, pp. 308-310; 1938, pp. $345-346$.

Ehser, A., Borg, G., \& Pernicka, E. (2011). Provenance of the gold of the early bronze age nebra sky disk, central Germany: Geochemical characterization of natural gold from Cornwall. European Journal of Mineralogy, 23(6), 895-910. 
Friedman, A. M., Conway, M., Kastner, M., Milsted, J., Metta, D., Fields, P. R., \& Olsen, E. (1966). Copper artifacts: correlation with some types of copper ores. Science 152:1504-1506

Gale, N. H., \& Stos-Gale, Z. A. (1981). Cycladic lead and silver metallurgy. Annual of British School at Athens, 76, 169-224

Gale, N. H., Gentner, W., \& Wagner, G. A. (1980). Mineralogical and geographical sources of Archaic Greek coinage. Metallurgy in Numismatics, 1, 3-49.

Gerlach, W., \& Schweitzer, E. (1930). Die chemische Emissionsspektralanalyse. Teil I. Leopold Voß, Leipzig.

Göbel, F. (1842). Über den Einfluß der Chemie auf die Ermittlung der Völker der Vorzeit oder Resultate der chemischen Untersuchung metallischer Alterthümer, insbesondere der in den Ostseegouvernements vorkommenden, behufs der Ermittlung der Völker, von welchen sie abstammen. Enke Verlag, Erlangen.

Gordus A. A. (1967). Quantitative non-destructive neutron activation analysis of silver in coins. Archaeometry, 10, 78-86.

Grögler, N., Geiss, J., Grünenfelder, M., \& Houtermans, F. G. (1966). Isotopenuntersuchungen zur Bestimmung der Herkunft römischer Bleirohre und Bleibarren. Zeitschr. f. Naturforsch, 2la, 1167-1172.

Guerra, M. F. (2004). Fingerprinting ancient gold with proton beams of different energies. Nuclear Instruments and Methods in Physics Research Section B, 226,185-198.

Härke, H. (1978). Probleme der optischen Emissionsspektralanalyse in der Urgeschichtsforschung. Prähist. Zeitschr, 53, 165-276.

Hall, E. T. (1970). Analytical techniques used in archaeometry. In: T. E. Allibone (Ed.), The impact of natural sciences on archaeology (pp. 135-141). Oxford University Press, London.

Hartmann, A. (1970). Prähistorische Goldfunde aus Europa. Studien zu den Anfängen der Metallurgie (SAM), Vol. 3. Gebr. Mann Verlag: Berlin.

Hartmann, A. (1982). Prähistorische Goldfunde aus Europa II. Studien zu den Anfängen der Metallurgie (SAM), Vol. 5. Gebr. Mann Verlag: Berlin.

Hauptmann, H., \& Pernicka, E. (Hrsg). (2004). Die Metallindustrie Mesopotamiens von den Anfängen bis zum 2. Jahrtausend v. Chr. Orient-Archäologie Band 3, Katalog, Tabellen, Tafeln. Rahden: Leidorf.

Hauptmann, A., Begemann, F., Heitkemper, E., Pernicka, E., \& Schmitt-Strecker S (1992). Early copper produced at Feinan, Wadi Araba, Jordan: The composition of ores and copper. Archeomaterials 6:1-33

Hauptmann, A., Rehren, Th., \& Pernicka, E. (1995). The composition of gold from the ancient mining district of Verespatak/Rošia Montana, Romania. In G. Morteani, \& J. P. Northover (Eds.), Prehistoric Gold in Europe (pp 369-381). Amsterdam: Kluwer Academic Publishers.

Hauptmann, A., Rehren, Th., \& Schmitt-Strecker, S. (2003). Early Bronze Age copper metallurgy at Shahr-i Sokhta (Iran), reconsidered. In Th. Stöllner, G. Körlin, G. Steffens, \& J. Cierny (Eds.), Man and Mining-Mensch und Bergbau. DerAnschnitt, Beiheft 16: 197-213. Deutsches Berbgau-Museum, Bochum.

Haustein, M., Gillis, C., \& Pernicka, E. (2010). Tin isotopy-A new method for solving old questions. Archaeometry, 52, 816-832.

Hedges, R. E. M., \& Salter, C. (1979). Source determination of iron currency bars through the analysis of slag inclusions. Archaeometry, 21, 161-175.

Hirao, Y., Enomoto, J., \& Tachikawa, H. (1995). Lead isotope ratios of copper, zinc and lead minerals in Turkey - In relation to the provenance study of artifacts. In H. I. H. Prince, \& T. Mikasa (Ed.), Essays on ancient Anatolia and its surrounding civilizations, pp. 89-114. Wiesbaden: Harrassowitz.

Hodson, F. R. (1969). Searching for structure within multivariate archaeological data. World Archaeology, 1, 90-105.

Höppner, B., Bartelheim, M., Huijsmans, M., Krauss, R., Martinek, K.-P., Pernicka, E., \& Schwab, R. (2005). Prehistoric copper production in the Inn valley, Austria, and the earliest copper in central Europe. Archaeometry, 47, 293-315. 
Junghans, S., Klein, H., \& Scheufele, E. (1954). Untersuchungen zur Kupfer- und Frühbronzezeit Süddeutschlands. Ber: RGK, 34, 77-114

Junghans, S., Sangmeister, E., \& Schröder, M. (1960). Metallanalysen kupferzeitlicher und frühbronzezeitlicher Bodenfunde aus Europa, Gebr. Mann Verlag, Berlin.

Junghans, S., Sangmeister, E., \& Schröder, M. (1968). Kupfer und Bronze in der frühen Metallzeit Europas 1-3, Berlin.

Junghans, S., Sangmeister, E., \& Schröder, M. (1974). Kupfer und Bronze in der frühen Metallzeit Europas 4, Gebr. Mann Verlag, Berlin.

Junk, S. A., \& Pernicka, E. (2003). An assessment of osmium isotope ratios as a new tool to determine the provenance of gold with platinum group metal inclusions. Archaeometry, 45, 313-331.

Klein, S., Brey, G. P., Durali-Müller, S., \& Lahaye, Y. (2010). Characterisation of the raw metal sources used for the production of copper and copper-based objects with copper isotopes. Archaeological and Anthropological Sciences, 2, 45-56.

Krause, R. (2003). Studien zur kupfer- und frühbronzezeitlichen Metallurgie zwischen Karpatenbecken und Ostsee. Rahden: VML Verlag.

Maddin, R., Stech Wheeler, T., \& Muhly, J. D. (1980). Distinguishing artifacts made of native copper. Journal of Archaeological Science, 7, 211-225.

Maréchal, J.-R. (1963). Reflections upon prehistoric metallurgy. A research based upon scientific methods. Lammersdorf: Junker.

Meeks, N. D., Tite, M. S. (1980). The analyses of platinum-group element inclusions in gold antiquities. Journal of Archaeological Science, 7, 267-275.

Meliksetian, K., \& Pernicka, E. (2010). Geochemical characterisation of Armenian early bronze age metal artefacts and their relation to copper ores. In S. Hansen, A. Hauptmann, I. Motzenbäcker, \& E. Pernicka (eds.), Von Maikop bis Trialeti. Gewinnung und Verbreitung von Metallen und Obsidian in Kaukasien im 4.-2. Jt. v. Chr. Beiträge des Internationalen Symposiums in Berlin vom 1.-3. Juni 2006. Kolloquien zur Vor- und Frühgeschichte, (Vol. 13, pp. 41-58). Habelt Verlag: Bonn.

Merkel, J. (1983). Summary of experimental results for Late Bronze Age copper smelting and refining. Museum Applied Science Center Journal, 2/6, 173-179.

Merkel, J. (1990). Experimental reconstruction of Bronze Age copper smelting based on archaeological evidence from Timna. In B. Rothenberg (Ed.), The ancient metallurgy of copper. London: Institute of Archaeo-Metallurgical Studies.

Nezafati, N., Pernicka, E., \& Momenzadeh, M. (2009). Introduction of the Deh Hosein Ancient Tin-Copper Mine, Western Iran: Evidence from geology, archaeology, geochemistry and lead isotope data. TÜBA-AR (Turkish Academy of Sciences Journal of Archaeology), 12, 223-236.

Northover, J. P. (1996). Comparison of metal analyses by different laboratories and methods, Appenidx II. In H. Vandkilde (Ed.), From stone to bronze: the metalwork of the Late Neolithic and earliest Bronze Age in Denmark (pp. 359-368). Moesgård: Jutland Archaeological Society/Jutland Archaeological Society Publications, 32.

Oldeberg, A. (1942). Metallteknik under förhistorisk tid. Part I. Otto Harrassowitz, Lund/Leipzig.

Otto, H., \& Witter, W. (1952). Handbuch der ältesten vorgeschichtlichen Metallurgie in Mitteleuropa. Leipzig: Barth Verlag.

Pare, C. F. E. (2000). Bronze and the Bronze Age. In C. F. E. Pare (Ed.), Metals make the world go round. The supply and circulation of metals in Bronze Age Europe (pp. 1-38). Oxbow, Oxford.

Pernicka, E. (1984). Instrumentelle Multi-Elementanalyse archäologischer Kupfer- und Bronzeartefakte Ein Methodenvergleich Jahrbuch Römisch-Germanisches Zentralmuseum 31, 517-531.

Pernicka, E. (1987). Erzlagerstätten in der Ägäis und ihre Ausbeutung im Altertum: Geochemische Untersuchungen zur Herkunftsbestimmung archäologischer Metallobjekte. Jahrbuch RömischGermanisches Zentralmuseum 34, 607-714.

Pernicka, E. (1990) Entstehung und Ausbreitung der Metallurgie in prähistorischer Zeit. Jahrb. Röm.-Germ. Zentralmus, 37, 21-129.

Pernicka, E. (1999). Trace element fingerprinting of ancient Copper: A guide to technology or provenance?. In S. M. M. Young, A. M. Pollard, P. Budd, \& R. A. Ixer (Eds.), Metals in antiquity. BAR International Series, 792 (pp. 163-171). Oxford: Archaeopress. 
Pernicka, E., Adam, K., Böhme, M., Hezarkhani, Z., Nezafati, N., Schreiner, M., Winterholler, B., Momenzadeh, M., \& Vatandoust, A. (2011). Archaeometallurgical researches at Arisman in central Iran. In A. Vatandoust, H. Parzinger, \& B. Helwing (eds.), Early mining and metallurgy on the Central Iranian Plateau. Report on the first five years of research of the Joint IranianGerman Research Project. Archäologie in Iran und Turản 9, 633-705, Philipp von Zabern, Mainz.

Pernicka, E., Begemann, F., Schmitt-Strecker, S., \& Wagner, G. A. (1993). Eneolithic and Early Bronze Age copper artefacts from the Balkans and their relation to Serbian copper ores. Praehistorische Zeitschrift, 68, 1-54.

Pernicka, E., Begemann, F., Schmitt-Strecker, S., Todorova, H., \& Kuleff, I. (1997). Prehistoric copper in Bulgaria: Its composition and provenance. Eurasia Antiqua, 3, 41-180.

Pittioni, R. (1957). Urzeitlicher Bergbau auf Kupfererz und Spurenanalyse. Beiträge zum Problem der Relation Lagerstätte-Fertigobjekt. Arch. Austriaca. Beih. 1, Wien.

Pollard, A. M., Thomas, R. G., Ware, D. P., \& Williams, P. A. (1991). Experimental smelting of secondary copper minerals: Implications for Early Bronze Age metallurgy in Britain. In E. Pernicka, G. A. Wagner (Eds.), Archaeometry '90 (pp. 127-136). Basel: Birkhäuser Verlag.

Preuschen, E., \& Pittioni, R. (1937). Untersuchungen im Bergbaugebiete Kelchalpe bei Kitzbühel, Tirol. Erster Bericht über die Arbeiten 1931-1936 zur Urgeschichte des Kupferbergwesens in Tirol. Mitt. Prähist. Komm. Volume 3.

Radivojević, M., Rehren, Th., Pernicka, E., ک̌ljivar, D., Brauns, M., \& Borić, D. (2010). On the origins of extractive metallurgy: new evidence from Europe. Journal of Archaeological Science, $37,2775-2787$.

Rehren, Th., Boscher, L., \& Pernicka, E. (2012). Large scale smelting of speiss and arsenical copper at Early Bronze Age Arisman, Iran. Journal of Archaeological Science, 39(6), 1717-1727.

Renfrew, C. (1973). Before civilization, Penguin, London.

Rychner, V., Kläntschi, N. (1995). Arsenic, Nickel et Antimoine. Cahiers d'Archéologie Romande, No. 63 and 64, Lausanne.

Sayre, E. V., Joel, E. C., Blackman, M. J., Yener, K. A., \& Özbal, H. (2001). Stable lead isotope studies of Black Sea Anatolian ore sources and related Bronze Age and Phrygian artefacts from nearby archaeological sites. Appendix:New Central Taurus ore data. Archaeometry, 43, 77-115.

Schmiderer A. (2008) Geochemische Charakterisierung von Goldvorkommen in Europa. Diss. Martin-Luther-Universität Halle-Wittenberg.

Schwab, R., Heger, D., Höppner, B., \& Pernicka, E. (2006). The provenance of iron artefacts from Manching: a multi-technique approach. Archaeometry, 48, 433-452.

Seeliger, T. C., Pernicka, E., Wagner, G. A., Begemann, F., Schmitt-Strecker, S., Eibner, C., Öztunali, Ö., \& Baranyi, I. (1985). Archäometallurgische Untersuchungen in Nord- und Ostanatolien. Jahrbuch Römisch-Germanisches Zentralmuseum, 32, 597-659.

Selimchanov, I. R. (1960). Spektralanalytische Untersuchungen von Metallfunden des 3. und 2. Jahrtausends aus dem östlichen Transkaukasien-Azerbeidshan. Archaeologia Austriaca, 28, $71-79$.

Slater, E. A., \& Charles, J. A. (1970). Archaeological classification by metal analysis. Antiquity, 44, 207-213.

Thornton, C. P., Rehren, Th. H., \& Pigott, V. C. (2009). The production of speiss (iron arsenide) during the Early Bronze Age in Iran. Journal of Archaeological Science, 36, 308-316.

Tylecote, R. F., Ghaznavi, H. A., \& Boydell, P. J. (1977). Partitioning of trace elements between the ores, fluxes, slags and metal during the smelting of copper. Journal of Archaeological Science, 4, 305-333.

von Bibra, E. (1869). Die Bronzen und Kupferlegierungen der alten und ältesten Völker, mit Rücksichtnahme auf jene der Neuzeit. Erlangen.

von Bibra, E. (1873). Über alte Eisen- und Silberfunde. Nürnberg and Leipzig.

von Fellenberg, L. R. (1860-1867). Analysen von antiken Bronzen. Mitt. D. naturf. Ges. Bern.

Wagner, G. A., Pernicka, E., Seeliger, T. C., Lorenz, I. B., Begemann, F., Schmitt-Strecker, S., Eibner, C., \& Öztunali, Ö. (1986). Geochemische und isotopische Charakteristika früher Rohstoffquellen für Kupfer, Blei, Silber und Gold in der Türkei. Jahrbuch Römisch-Germanisches Zentralmuseum, 33, 723-752. 
Wagner, G. A., Begemann, F., Eibner, C., Lutz, J., Öztunali, Ö., Pernicka, E., \& SchmittStrecker, S. (1989). Archäometallurgische Untersuchungen an Rohstoffquellen des frühen Kupfers Ostanatoliens. Jahrbuch Römisch-Germanisches Zentralmuseum, 36, 637-686.

Wagner, G. A., Wagner, I., Öztunali, Ö., Schmitt-Strecker, S., Begemann, F. (2003). Archäometallurgischer Bericht über Feldforschung in Anatolienund bleiisotopische Studien an Erzen und Schlacken. In: Stöllner, T., Körlin, G. Steffens G. \& Cierny J. (Eds.), Man and Mining-Mensch und Bergbau. Der Anschnitt, Beiheft 16: 475-494, Deutsches Bergbau-Museum, Bochum.

Waterbolk, H. T., \& Butler, J. J. (1965). Comments on the use of metallurgical analysis in prehistoric studies. Helinium, 5, 227-251.

Wibel, F. (1863). Beitrag zur Kenntnis antiker Bronzen vom chemischen Standpunkte. Hamburg.

Woolley, C. L. (1931). Excavations at Ur, 1930-1. The Antiquaries Journal, 11, 344.

Wyttenbach, A., \& Schubiger, P. A. (1973). Trace element content of Roman lead by neutron activation analysis. Archaeometry, 15, 199-207.

Yener, K. A., Sayre, E. V., Joel, E. C., Özbal, H., Barnes, I. L., \& Brill, R. H. (1991). Stable lead isotope studies of Central Taurus ore sources and related artifacts from Eastern Mediterranean Chalcolithic and Bronze Age sites. Journal of Archaeological Science, 18, 541-577.

Young, W. J. (1972). The fabulous gold of the Pactolus valley. Bull.- Boston Museum of Fine Arts, 70/359, 4-13. 